\title{
Economic freedom and human capital investment
}

\author{
HORST FELDMANN* \\ Department of Economics, University of Bath, Bath, UK
}

\begin{abstract}
Using data from 1972 to 2011 on 109 countries, this paper empirically studies the impact of economic freedom on human capital investment. Enrollment in secondary education is used as a proxy for such investments. Controlling for a large number of other determinants of education, it finds that, over the sample period, economic freedom had a substantial positive effect. This is probably because more economic freedom increases the return on investing in human capital, enables people to keep a larger share of the return, and, by facilitating the operation of credit markets, makes it easier for them to undertake such investments in the first place.
\end{abstract}

\section{Introduction}

In recent decades, both the study of economic freedom and the study of human capital investment have become important areas of research (for surveys, see Burton-Jones and Spender, 2011; Hall and Lawson, 2014). However, it has hardly been analyzed so far whether economic freedom affects human capital investment. Why might there be such an effect? One possible reason was advanced by Schultz (1975), who argued that returns to human capital are highest if government does not restrict the ability of firms and individuals to adapt to unexpected price, productivity and technology shocks - i.e., if there is a high degree of economic freedom. By contrast, if government severely restricts economic freedom, this would limit the degree to which firms and individuals can react to such shocks, substantially reducing returns to human capital. While in the latter scenario, individuals and firms would be induced to invest less in their human capital or in that of their employees, in the former scenario they would be induced to invest more.

More generally, one can expect economic freedom to affect human capital investment for similar reasons as to why it usually affects investment in physical capital (on the latter, see, e.g., Besley, 1995). There are three main reasons. First, as key elements of economic freedom include secure property rights, a low level of taxation and monetary stability, it protects economic agents both from expro-

*Email: h.feldmann@bath.ac.uk 
priation and from dilution of their property rights through high taxation or high inflation. Individuals and firms thus have an incentive to invest in both physical and human capital because they can enjoy the fruits of their investments. For the same reason, parents have an incentive to invest in their children's human capital.

A second reason as to why economic freedom is likely to stimulate investment in human capital is that the former enhances the gains from economic exchange. Key elements of economic freedom relevant here are the rule of law and a light regulatory burden, especially on product and labor markets, as well as low tariff and non-tariff barriers to international trade. These elements, as well as other elements of economic freedom such as modest taxation, incentivize individuals to maximize the return on their human capital by engaging in economic exchange. Additionally, they enable firms to employ workers efficiently. These effects in turn provide individuals (including parents) and firms with strong incentives to invest in human capital.

Third, economic freedom is likely to stimulate investment in human capital because it facilitates the operation of credit markets. Key elements of economic freedom relevant here are secure property rights (including an effective protection of investors and the right to use property as collateral) and a pro-competitive regulation of those markets. Investment in human capital - schooling, in particular - entails a large upfront fixed cost while the return in form of higher wages accrues throughout working life. Thus, parents often need to take out loans to invest in their children's education. The easier it is to use property as collateral and the more competitive credit markets are, the easier and cheaper it is for them to do so. Firms' training of workers - apprenticeships, in particular - also entails a substantial upfront investment in human capital, with returns accruing over many subsequent years of employment. Firms' costs to invest in the human capital of their employees are also lower, the more secure property rights and the more competitive credit markets are, as firms usually fund investment through loans. Obviously, this too is similar to investment in physical capital. ${ }^{1}$

So far, there are only three previous papers empirically studying the effect of economic freedom on human capital investment. The first one, by Dawson (1998), only briefly touches upon the issue as it is mainly concerned with the determinants of economic growth and physical investment. However, it also reports the results from a few regressions to explain the secondary school enrollment rate. In these regressions, which use cross-sectional data on 84 countries from the period 1975 to 1990, Dawson (1998) finds a positive association with change in economic freedom. The second paper, by Aixalá and Fabro (2009), also touches upon the issue only briefly; it mainly studies the effects of economic and political freedom on economic growth. Using data on 112 countries over 1976 to 2000, it finds that economic freedom Granger-causes

\footnotetext{
1 See, e.g., Demirgüç-Kunt and Maksimovic (1998) who find that firms invest more from external funds in physical capital in countries with secure property rights.
} 
primary school enrollment. The third paper is by King et al. (2012), who use data on 86 developing countries from the period 1989 to 2007 . They find returns to both schooling and work experience to be substantially higher in economically free countries. According to their regression results, those benefits go to men as well as women.

These three papers take important first steps. Using data on more than 100 countries, we add to this nascent literature in three respects. Most importantly, our paper is the first to put the impact of economic freedom on the extent of human capital investment center stage. By contrast, both Dawson (1998) and Aixalá and Fabro (2009) deal with the issue only marginally, and King et al. (2012) study the effect on returns to, rather than on the extent of, human capital investment. Second, we control for a much larger number of other determinants of human capital investment. While both Dawson (1998) and Aixalá and Fabro (2009) use hardly any controls, the number of controls in King et al.'s (2012) paper is small. Our third contribution is that we study the effect of economic freedom on human capital investment not only among males and females jointly but also separately for females. While neither Dawson (1998) nor Aixalá and Fabro (2009) do this, King et al. (2012), who do look at females separately, study a slightly different research question.

The remainder of the paper is organized as follows. While section 2 describes our variables, section 3 explains the methodology used. Section 4 presents and discusses our regression results. Section 5 concludes.

\section{Variables}

We use the 'Economic Freedom of the World (EFW)' index (for definitions, descriptive statistics and sources of all variables, see Table A1). It is the most widely used index of economic freedom and is generally considered to be the best because it covers all major aspects of economic freedom, uses data from reputable external sources (such as the World Bank and the IMF), almost exclusively relies on hard data, covers a large number of countries and is available since $1970 .^{2}$ The EFW index comprises 42 distinct variables that are organized into five areas: size of government, legal system and property rights, sound money, freedom to trade internationally and regulation. The summary ratings of the index are the arithmetic means of the area ratings. We use these summary ratings rather than the area ratings because, as explained in the previous section, the various components of economic freedom are interrelated and likely to affect human capital investment jointly. ${ }^{3}$ The summary ratings used are chain-linked, which

\footnotetext{
2 By contrast, the 'Index of Economic Freedom' published by the Heritage Foundation and the Wall Street Journal partly relies on subjective assessments of in-house experts and is available since 1995 only (Miller and Kim, 2016).

3 Results from regressions using the area ratings are available upon request.
} 
accounts for the fact that the number and composition of the components has changed over time as the index has become more comprehensive and available data more complete. The chain-linked ratings are consistent both across countries and through time.

Our main human capital investment variable is the secondary school enrollment rate. Education is widely regarded as the most important form of human capital investment. We use the secondary rather than the primary enrollment rate because in most countries primary education has been compulsory for many years. In addition to the secondary enrollment rate, which covers boys and girls jointly, we also use the female secondary enrollment rate. This is because the education of girls has traditionally been neglected in many countries. Using the female secondary enrollment rate as an alternative dependent variable enables us to gauge whether and to what extent economic freedom has benefited this demographic group in particular.

Although it is common in the literature to use secondary school enrollment as a proxy for human capital investment (e.g., Crespo Cuaresma, 2010; Flug et al., 1998; Papagapitos and Riley, 2009), our dependent variables have the downside of being narrow measures of such investments. Apart from secondary education, there is primary and tertiary education. Furthermore, our measures capture neither training of workers nor investment in health, both of which are important forms of human capital investment too. Studying the effects of economic freedom on these types of human capital formation is an important area for future research.

We include a large number of variables to control for the impact of factors that, according to the relevant literature, are potentially important determinants of education. Our first control is 'political freedom', which is constructed as the average of the political rights and civil liberties ratings produced annually by Freedom House. In one robustness checks, we replace 'political freedom' by 'democracy'. ${ }^{4}$ This index measures the degree of autocracy/democracy and is constructed as part of the Polity IV project. We use 'political freedom' or, alternatively, 'democracy' for two reasons. First, to ensure that 'economic freedom' does not proxy for either of them. And second, to check whether political freedom or democracy exert an influence of their own on human capital investment. Indeed, several studies find political freedom or democracy to have a positive impact on enrollment rates (e.g., Eterovic and Sweet, 2014; Lake and Baum, 2001; Rudra and Haggard, 2005). By contrast, Glaeser et al. (2004) are unable to find any effect of political institutions.

We also control for public spending on education. Higher spending should foster human capital formation. A couple of previous empirical studies do find such a positive effect (Castelló-Climent and Hidalgo-Cabrillana, 2012; Heylen

\footnotetext{
${ }^{4}$ We do not use both variables jointly because they are highly correlated. By contrast, 'economic freedom' is not highly correlated with either of them.
} 
and Pozzi, 2007). By contrast, neither Flug et al. (1998) nor Papagapitos and Riley (2009) are able to find a statistically significant effect on the secondary enrollment rate.

We also use several demographic variables. For example, we include the population growth rate. Lower population growth could lead to a higher secondary enrollment rate. This is because both parents and societies face a trade-off between child quantity and quality: The lower the number of children, the more they are usually able to invest into each of them (e.g., Becker and Lewis, 1973; Hanushek, 1992).

A large theoretical literature argues that improvements in life expectancy or mortality should increase investment in human capital (e.g., Cervellati and Sunde, 2005; Kalemli-Ozcan et al., 2000; Soares, 2005). Indeed, many empirical papers find life expectancy to have a positive effect and mortality, including parental death, to have a negative effect on schooling (e.g., Boikos et al., 2013; Forston, 2011; Stoler and Meltzer, 2013). Therefore, we use both 'life expectancy' and 'death rate'.

Additionally, we control for urbanization because access to school is usually better in urban areas than in rural ones. Castello-Climent and HidalgoCabrillana (2012) find that a higher urbanization rate is related to higher levels of secondary education. By contrast, the relevant coefficient is insignificant in Papagapitos and Riley's (2009) regressions.

We control for all major religions: Protestantism, Catholicism, Islam and Eastern religions. Protestantism has always stressed the importance of education (e.g., Becker and Woessmann, 2009). The effects of Catholicism in previous empirical studies is mixed (e.g., Neal, 1997; Sherkat, 2011). By contrast, a large number of empirical studies consistently find Islam to have a negative impact on education, particularly among females (e.g., Cooray and Potrafke, 2011; Feldmann, 2016a; Norton and Tomal, 2009). The effects of Eastern religions have been little researched so far, with inconclusive results (e.g., Bessey, 2013; Feldmann, 2016a; Norton and Tomal, 2009). This is despite the fact that two of them, Buddhism and Confucianism, have traditionally highly valued education. In one robustness check, we additionally control for religious pluralism because Alesina et al. (2003) and Gruber (2005) suggest that it might favorably affect education.

We also control for relevant economic characteristics. For example, we include GDP per capita - not only because many previous papers find a positive effect on schooling (e.g., Mincer, 1996) but also to ensure that economic freedom does not proxy for GDP per capita, given that most richer countries have more economic freedom. ${ }^{5}$ Furthermore, we control for GDP growth because results for the US suggest that schooling is countercyclical (e.g., Méndez and Sepúlveda, 2012).

\footnotetext{
${ }^{5}$ Although GDP per capita is positively correlated with economic freedom, the size of the correlation is moderate.
} 
Additionally, we use 'private credit' as a proxy for borrowing constraints. De Gregorio (1996), among others, theoretically argues and empirically shows that such constraints can have a negative effect on the secondary enrollment rate. We also include 'physical capital stock' and, in one robustness check, 'physical investment'. The intention here is to capture the complementarity or substitutability of physical and human capital, similar to Griliches (1969). Furthermore, we control for trade openness because several theoretical papers argue that it might affect human capital accumulation, either positively or negatively (e.g., Ranjan, 2001).

In one robustness check, we additionally control for income inequality. According to the relevant theoretical papers, the effect of income inequality can also be either positive or negative, depending on the circumstances (e.g., Chiu, 1998; Grossmann, 2008). The results from previous empirical research are mixed (e.g., Flug et al., 1998; Papagapitos and Riley, 2009). In our final four robustness checks, we additionally control for economic instability and different types of crises. As several papers show theoretically and/or empirically, they too can positively or negatively affect investment in human capital (e.g., Crespo Cuaresma, 2010; Heylen and Pozzi, 2007; Skidmore and Toya, 2002).

\section{Sample and methodology}

Our sample covers 109 countries over the period from 1972 to 2011 (for a list of countries, see Appendix B). With respect to both countries and years, the size of our sample is determined by data availability only. Using data from as large a sample as possible leads to the most general results.

We constructed our dataset in three steps. First, we collected panel data at annual frequency, covering as many countries and years as possible. In a second step, we filled gaps in the data. Specifically, because prior to 2000 the EFW index is available at 5-year intervals only, we filled the gaps by linear interpolation. This is justifiable because the EFW ratings usually change only gradually over time. For our other variables, we also filled any gaps in the data by linear interpolation. As in the case of 'economic freedom', the data for most of these variables - e.g., the enrollment and the religion variables - also change only gradually over time. Those that display swings from year to year, such as the GDP growth rate, did not have any gaps at all. In the third step of constructing our dataset, we averaged the annual data over non-overlapping 5 -year periods. This eliminates noise, reduces measurement error and, because in our regressions we lag our explanatory variables by one period (see below), makes it more likely that our estimates capture the effect of economic freedom on human capital investment.

There is substantial variation in both the economic freedom measure and the two enrollment variables. Specifically, on a 0-to-1 scale, 'economic freedom' ranges from 0.29 to 0.86 (Table A1). The secondary enrollment rate ranges 
Figure 1. Economic freedom and secondary enrollment rate.

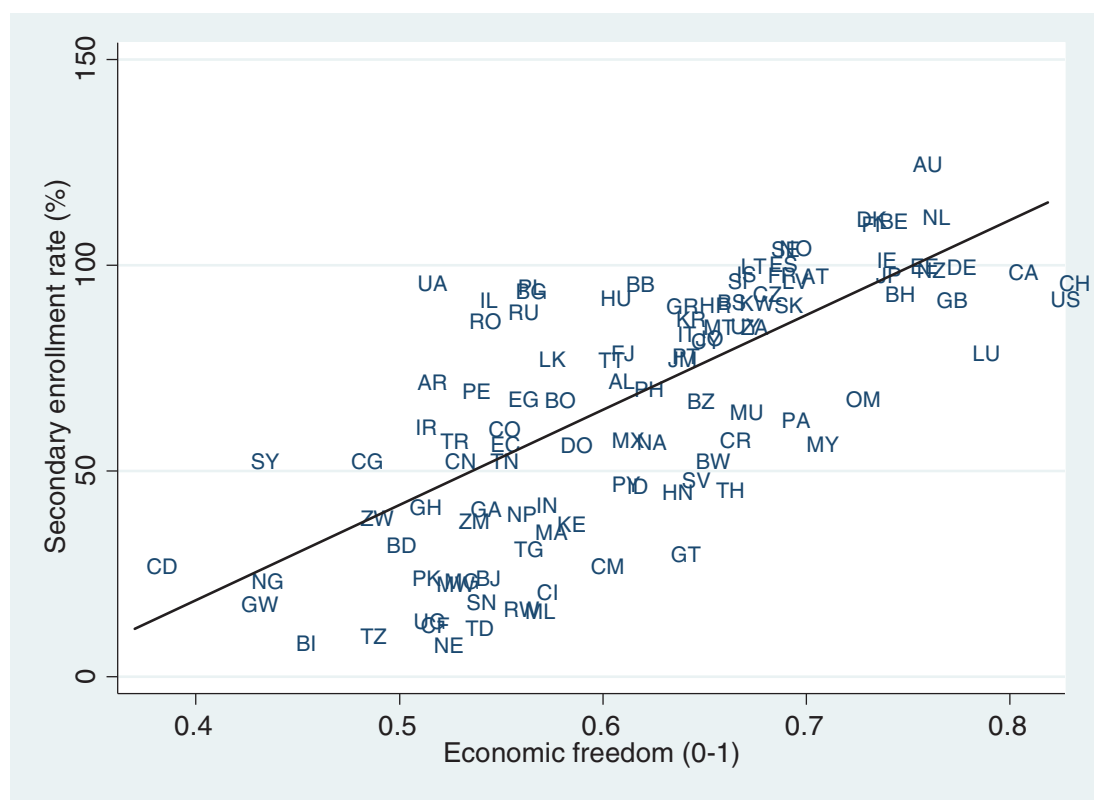

Notes: 109 countries. Data from the period 1972 to 2011 . The regression represented by the fitted line yields a coefficient on 'economic freedom' of 231.02 (robust standard error $=20.24$ ), $N=109$, $R^{2}=0.51$.

from $3.4 \%$ to $154.8 \%$, while the female secondary enrollment rate ranges from $2.3 \%$ to $167.4 \%$. For all three measures, the variation is not only large between countries (Figures 1 and 2), it is also large (though slightly smaller) within them. Specifically, the within-panel variation ranges from 0.41 to 0.84 for 'economic freedom', from $38.3 \%$ to $110.6 \%$ for the secondary enrollment rate and from $37.1 \%$ to $120.6 \%$ for the female secondary enrollment rate.

We estimate the following model:

$$
S_{i, t}=\gamma E_{i, t-1}+\sum_{k=1}^{q} \beta_{k} X_{k, i, t-1}+\alpha_{i}+\lambda_{t}+\varepsilon_{i, t}
$$

$S_{i, t}$ is a secondary enrollment rate variable of country $i$ in 5 -year period $t$, either covering both genders jointly or girls only. $E_{i, t-1}$ denotes the 'economic freedom' variable and $X_{k, i, t-1}$ represents a vector of $q$ control variables. While $\alpha_{i}$ and $\lambda_{t}$ are country and period fixed effects, respectively, $\varepsilon_{i, t}$ is the error term. Country fixed effects are included to control for the impact of unobserved country-specific characteristics. They are also useful in removing omitted factors that influence both secondary enrollment and economic freedom in the long run. Period fixed effects are included to control for the impact of shocks that are common across countries. Additionally, they ensure that our estimates do not reflect over-time 
Figure 2. Economic freedom and female secondary enrollment rate.

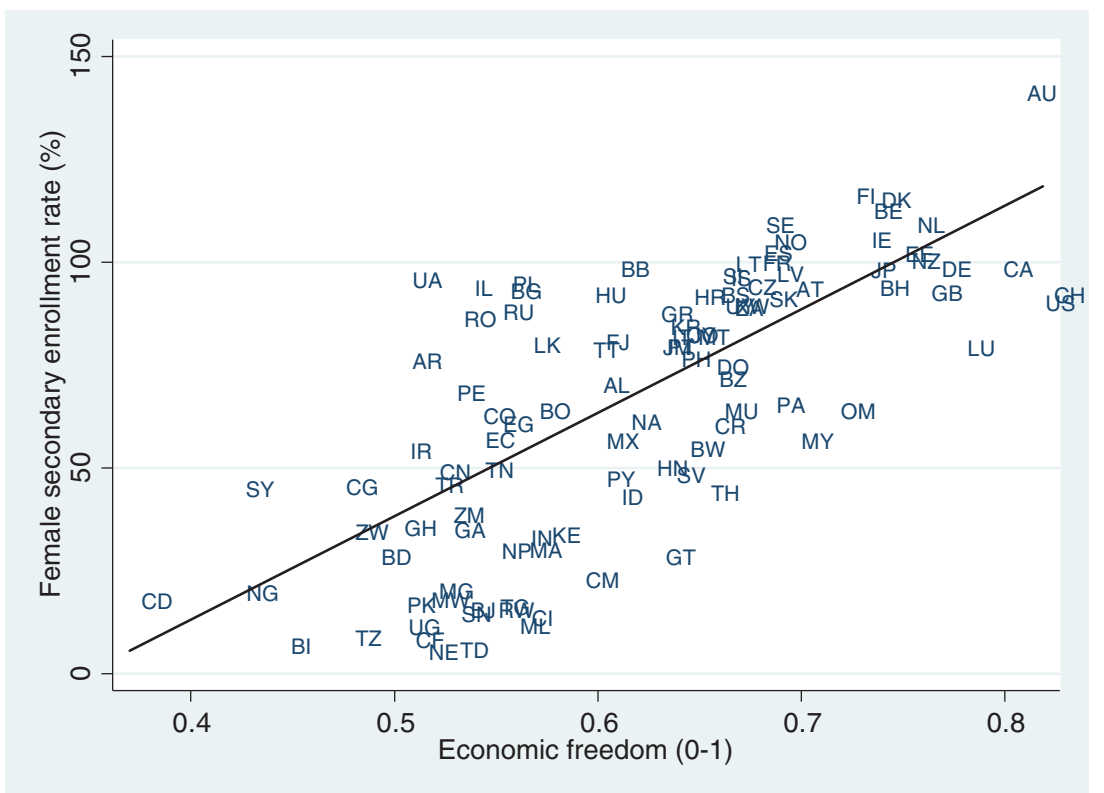

Notes: 108 countries. Data from the period 1972 to 2011. The regression represented by the fitted line yields a coefficient on 'economic freedom' of 251.69 (robust standard error $=22.20$ ), $N=108$, $R^{2}=0.52$.

trends in secondary enrollment or economic freedom at the world level over the sample period. More generally, by using both country and period fixed effects plus a large number of control variables, we intend to ensure that our regression analysis accounts for other factors than economic freedom that affect secondary enrollment, some of which may be correlated with economic freedom.

If applicable, a random effects estimator would be more efficient because it exploits both the cross-country and the time-series variation included in the sample. By contrast, fixed effects models only use the time-series variation. However, we cannot use a random effects estimator here because the results from the Hausman (1978) test indicate that, in most cases, such an estimator yields biased estimates (results not reported here). In any case, fixed effects regressions are likely to provide more convincing and relevant conditional correlations as they focus on whether enrollment rates changed following changes in economic freedom.

Causality may not only run from economic freedom to education but also vice versa. As people become more educated, they may well demand more economic freedom. This reasoning is akin to Lipset (1960), who believed that educated people are more likely to resolve their differences through courts, negotiations and voting, rather than through violence. They would thus build 'good' legal and political institutions. However, whereas there is considerable empirical support 
for Lipset's hypothesis (e.g., Barro, 1999), only one empirical study indicates that education might cause economic freedom. Specifically, Aixalá and Fabro (2009) find bidirectional Granger causality between economic freedom and primary school enrollment: In their data, not only does economic freedom Granger-cause primary school enrollment but also vice versa. As mentioned in section 1, they use hardly any controls though.

In any case, endogeneity of 'economic freedom' cannot be ruled out. Some or all of our control variables may be endogenous too. Unfortunately, there are no valid instruments. For example, we tried GMM. However, the results from the Hansen (1982) test of overidentifying restrictions produced high $p$ values throughout, suggesting that GMM would be inappropriate in our case. The problem is probably one of instrument proliferation, i.e., the fact that the number of instruments in GMM tends to explode with the number of time periods. Instrument proliferation can overfit endogenous variables and fail to expunge their endogenous components, a telltale sign being high Hansen test $p$ values (Roodman, 2009a, 2009b). We experimented with various ways of reducing the instrument count, such as limiting the lags in GMMstyle instruments and collapsing instruments, but none of them solved the problem.

We also tried two stage least squares (2SLS) estimation. As instruments for economic freedom, we used variables that have been suggested (for economic freedom or something similar) in the previous literature. Specifically, in this exercise, we used the variables 'English language', 'Western European languages' (defined as fraction of the population speaking one of these languages as a mother tongue) and legal origins (Hall and Jones, 1999; La Porta et al., 1999). Faria and Montesinos (2009), who focus on instrumenting for economic freedom, additionally use ethnolinguistic fractionalization, latitude and European settler mortality. We used neither of these three variables. According to other research, both ethnic fractionalization and latitude have a direct effect on education (Alesina et al., 2003; Feldmann, 2016b). Data on European settler mortality are available for comparatively few countries (Acemoglu et al., 2001). The same is true for 'pronoun drop', yet another potential instrument (Davis and Abdurazokzoda, 2016). As the language and legal origins data we used are time-invariant (as are the other potential instruments mentioned), we employed cross-country rather than panel data in our 2SLS exercise. To calculate country averages, we selected only data from years for which EFW data are available. As part of the exercise, we performed various tests of instrument validity. Specifically, to test for underidentification, we used the Kleibergen and Paap (2006) rk LM test. To test for instrument relevance, we calculated Shea's (1997) partial $R^{2}$ statistic and performed an $F$ test of excluded instruments (Staiger and Stock, 1997). Finally, we applied Hansen's (1982) test of overidentifying restrictions. These tests revealed that the instruments are weak and, in most cases, not exogenous. Thus, they are invalid. Furthermore, the instruments we 
tried, as well as the other potential instruments mentioned above, have two conceptual problems. First, they are not specific enough to economic freedom. Excluded instruments need to be specific to the instrumented variable (Acemoglu, 2005). Second, previous studies have used them as instruments for various other variables. ${ }^{6} \mathrm{~A}$ variable can be a valid instrument in at most one such study (Bazzi and Clemens, 2013).

Using our panel dataset, we also tried Hausman and Taylor's (1981) instrumental variables estimator. However, the resulting estimates do not pass the Hausman (1978) test, suggesting that they are biased and the instruments invalid. As instrumental variable estimation is not applicable, we lag all explanatory variables by one period. It is very well possible that current economic freedom affects secondary school enrollment in the following 5-year period. By contrast, it is hard to imagine future enrollment to affect current freedom. Thus, using a lag increases the likelihood that our estimates reflect the influence of economic freedom on secondary enrollment rather than the other way around. The same considerations apply to our control variables.

To further examine the possibility of reverse causality, we run additional regressions in which we swap the respective enrollment variable and our variable of interest. Thus, in these regressions we use 'economic freedom' as dependent variable and the respective enrollment variable, lagged by one period, as an explanatory variable. The control variables, also lagged by one period, and the estimation method are the same as in the respective regressions to explain the secondary (or female secondary) enrollment rate. The $p$ values of the coefficients on the enrollment variables from this reverse causality test are reported in Table 1. As they indicate, the coefficients are statistically insignificant throughout. This test therefore does not provide any evidence of causality running from secondary schooling to economic freedom.

Although there is no evidence of reverse causality, the regressions presented in Table 1 do not prove that causality runs from economic freedom to secondary schooling because there are no valid instruments to address potential endogeneity. Instead, these regressions are used to measure conditional correlations, i.e., to assess whether 'economic freedom' is statistically significant after controlling for other relevant factors. Still, the estimates for our variable of interest are likely to be causal for five reasons. First, we control for most major determinants of school enrollment that have been found in the previous literature. Second, we also control for unobserved country and period effects. Third, we ensure that 'economic freedom' does not proxy for factors such as political freedom or GDP per capita. Fourth, all explanatory variables enter the

\footnotetext{
${ }^{6}$ For example, while the language variables we used have previously been employed as instruments for 'social infrastructure' (Hall and Jones, 1999), legal origins have previously been employed as instruments for a host of institutions and policy outcomes (Bazzi and Clemens, 2013).
} 
Table 1. Fixed effects regressions of secondary school enrollment

\begin{tabular}{|c|c|c|c|c|c|c|c|c|c|}
\hline & $\begin{array}{l}\text { (1) } \\
\text { Baseline } \\
\text { specification }\end{array}$ & $\begin{array}{l}(2) \\
\text { Democracy } \\
\text { substituted for } \\
\text { political freedom }\end{array}$ & $\begin{array}{l}(3) \\
\text { Religious } \\
\text { pluralism } \\
\text { added }\end{array}$ & $\begin{array}{l}(4) \\
\text { Physical } \\
\text { investment } \\
\text { added }\end{array}$ & $\begin{array}{l}(5) \\
\text { Income } \\
\text { inequality } \\
\text { added }\end{array}$ & $\begin{array}{l}(6) \\
\text { Inflation } \\
\text { rate } \\
\text { added }\end{array}$ & $\begin{array}{l}(7) \\
\text { Systemic } \\
\text { banking crises } \\
\text { added }\end{array}$ & $\begin{array}{l}(8) \\
\text { Natural } \\
\text { disasters } \\
\text { added }\end{array}$ & $\begin{array}{l}\text { (9) } \\
\text { Wars } \\
\text { added }\end{array}$ \\
\hline \multicolumn{10}{|c|}{ Panel A. Dependent variable: secondary enrollment rate } \\
\hline Economic freedom & $\begin{array}{c}33.48^{* *} \\
(12.75)\end{array}$ & $\begin{array}{c}31.74^{* *} \\
(12.95)\end{array}$ & $\begin{array}{l}34.20^{* * *} \\
(12.92)\end{array}$ & $\begin{array}{l}31.89^{* *} \\
(12.18)\end{array}$ & $\begin{array}{l}37.98^{* * *} \\
(12.92)\end{array}$ & $\begin{array}{l}33.84^{* *} \\
(12.90)\end{array}$ & $\begin{array}{l}33.50^{* *} \\
(12.78)\end{array}$ & $\begin{array}{l}33.71^{* * *} \\
(12.69)\end{array}$ & $\begin{array}{l}33.02^{* *} \\
(12.81)\end{array}$ \\
\hline Political freedom & $\begin{array}{c}-2.75 \\
(3.33)\end{array}$ & & $\begin{array}{c}-2.69 \\
(3.31)\end{array}$ & $\begin{array}{c}-2.71 \\
(3.34)\end{array}$ & $\begin{array}{r}-3.07 \\
(3.74)\end{array}$ & $\begin{array}{r}-2.78 \\
(3.33)\end{array}$ & $\begin{array}{c}-2.74 \\
(3.33)\end{array}$ & $\begin{array}{r}-2.99 \\
(3.35)\end{array}$ & $\begin{array}{r}-2.92 \\
(3.35)\end{array}$ \\
\hline Public spending on education & $\begin{array}{r}-10.76 \\
(29.14)\end{array}$ & $\begin{array}{l}-9.07 \\
(29.12)\end{array}$ & $\begin{array}{r}-14.16 \\
(31.01)\end{array}$ & $\begin{array}{r}-12.33 \\
(29.98)\end{array}$ & $\begin{array}{l}-5.83 \\
(33.06)\end{array}$ & $\begin{array}{r}-10.74 \\
(29.26)\end{array}$ & $\begin{array}{r}-10.88 \\
(29.30)\end{array}$ & $\begin{array}{r}-11.03 \\
(29.27)\end{array}$ & $\begin{array}{r}-11.33 \\
(29.23)\end{array}$ \\
\hline Population growth rate & $\begin{array}{r}-19.23 \\
(71.31)\end{array}$ & $\begin{array}{r}-28.21 \\
(71.21)\end{array}$ & $\begin{array}{r}-16.65 \\
(72.24)\end{array}$ & $\begin{array}{r}-20.44 \\
(72.61)\end{array}$ & $\begin{array}{c}31.97 \\
(76.26)\end{array}$ & $\begin{array}{r}-19.90 \\
(71.34)\end{array}$ & $\begin{array}{r}-19.23 \\
(71.37)\end{array}$ & $\begin{array}{r}-15.11 \\
(72.89)\end{array}$ & $\begin{array}{r}-16.92 \\
(71.89)\end{array}$ \\
\hline Life expectancy & $\begin{array}{c}0.68 \\
(0.53)\end{array}$ & $\begin{array}{c}0.70 \\
(0.55)\end{array}$ & $\begin{array}{c}0.66 \\
(0.53)\end{array}$ & $\begin{array}{c}0.67 \\
(0.53)\end{array}$ & $\begin{array}{c}0.56 \\
(0.58)\end{array}$ & $\begin{array}{c}0.67 \\
(0.53)\end{array}$ & $\begin{array}{c}0.68 \\
(0.53)\end{array}$ & $\begin{array}{c}0.69 \\
(0.55)\end{array}$ & $\begin{array}{c}0.67 \\
(0.53)\end{array}$ \\
\hline Death rate & $\begin{array}{c}1.25^{*} \\
(0.74)\end{array}$ & $\begin{array}{c}1.27 \\
(0.77)\end{array}$ & $\begin{array}{r}1.26^{*} \\
(0.74)\end{array}$ & $\begin{array}{c}1.29^{*} \\
(0.75)\end{array}$ & $\begin{array}{c}1.23 \\
(0.78)\end{array}$ & $\begin{array}{c}1.25^{*} \\
(0.74)\end{array}$ & $\begin{array}{c}1.25^{*} \\
(0.74)\end{array}$ & $\begin{array}{c}1.28^{*} \\
(0.77)\end{array}$ & $\begin{array}{c}1.25^{*} \\
(0.74)\end{array}$ \\
\hline Urbanization rate & $\begin{array}{c}34.70 \\
(23.00)\end{array}$ & $\begin{array}{c}30.27 \\
(24.73)\end{array}$ & $\begin{array}{c}33.59 \\
(22.78)\end{array}$ & $\begin{array}{c}32.89 \\
(23.32)\end{array}$ & $\begin{array}{c}31.30 \\
(23.93)\end{array}$ & $\begin{array}{c}34.82 \\
(23.00)\end{array}$ & $\begin{array}{c}34.72 \\
(22.99)\end{array}$ & $\begin{array}{c}35.63 \\
(22.72)\end{array}$ & $\begin{array}{c}34.39 \\
(23.05)\end{array}$ \\
\hline Protestant population & $\begin{array}{c}1.36 \\
(17.90)\end{array}$ & $\begin{array}{c}3.39 \\
(18.56)\end{array}$ & $\begin{array}{r}-10.31 \\
(20.76)\end{array}$ & $\begin{array}{c}0.72 \\
(17.60)\end{array}$ & $\begin{array}{c}3.38 \\
(18.23)\end{array}$ & $\begin{array}{c}1.29 \\
(17.88)\end{array}$ & $\begin{array}{c}1.26 \\
(17.83)\end{array}$ & $\begin{array}{c}1.28 \\
(18.06)\end{array}$ & $\begin{array}{c}1.38 \\
(17.93)\end{array}$ \\
\hline Roman Catholic population & $\begin{array}{l}-2.10 \\
(20.05)\end{array}$ & $\begin{array}{l}-0.90 \\
(20.26)\end{array}$ & $\begin{array}{r}-12.16 \\
(21.63)\end{array}$ & $\begin{array}{l}-2.36 \\
(19.85)\end{array}$ & $\begin{array}{c}3.33 \\
(21.45)\end{array}$ & $\begin{array}{l}-2.58 \\
(20.16)\end{array}$ & $\begin{array}{l}-2.05 \\
(20.19)\end{array}$ & $\begin{array}{l}-2.48 \\
(20.07)\end{array}$ & $\begin{array}{l}-1.63 \\
(20.05)\end{array}$ \\
\hline Muslim population & $\begin{array}{c}-67.04^{* *} \\
(31.12)\end{array}$ & $\begin{array}{c}-68.72^{* *} \\
(30.94)\end{array}$ & $\begin{array}{c}-69.01^{* *} \\
(31.65)\end{array}$ & $\begin{array}{c}-67.00^{* *} \\
(31.66)\end{array}$ & $\begin{array}{r}-48.56 \\
(37.37)\end{array}$ & $\begin{array}{c}-66.91^{* *} \\
(31.16)\end{array}$ & $\begin{array}{c}-67.20^{* *} \\
(31.28)\end{array}$ & $\begin{array}{c}-67.37^{* *} \\
(30.98)\end{array}$ & $\begin{array}{c}-67.34^{* *} \\
(31.02)\end{array}$ \\
\hline Eastern religions population & $\begin{array}{c}21.55 \\
(46.90)\end{array}$ & $\begin{array}{c}25.46 \\
(44.87)\end{array}$ & $\begin{array}{c}15.03 \\
(47.53)\end{array}$ & $\begin{array}{c}21.52 \\
(46.53)\end{array}$ & $\begin{array}{c}10.57 \\
(56.26)\end{array}$ & $\begin{array}{c}21.29 \\
(46.88)\end{array}$ & $\begin{array}{c}21.66 \\
(46.94)\end{array}$ & $\begin{array}{c}20.06 \\
(47.31)\end{array}$ & $\begin{array}{c}20.88 \\
(47.17)\end{array}$ \\
\hline GDP per capita & $\begin{array}{r}-1.55 \\
(2.68)\end{array}$ & $\begin{array}{r}-1.45 \\
(2.70)\end{array}$ & $\begin{array}{r}-1.38 \\
(2.62)\end{array}$ & $\begin{array}{r}-1.49 \\
(2.67)\end{array}$ & $\begin{array}{r}-4.54 \\
(3.04)\end{array}$ & $\begin{array}{r}-1.56 \\
(2.68)\end{array}$ & $\begin{array}{r}-1.53 \\
(2.68)\end{array}$ & $\begin{array}{r}-1.54 \\
(2.68)\end{array}$ & $\begin{array}{r}-1.63 \\
(2.68)\end{array}$ \\
\hline
\end{tabular}


Table 1. (Continued)

\begin{tabular}{|c|c|c|c|c|c|c|c|c|c|}
\hline & $\begin{array}{l}\text { (1) } \\
\text { Baseline } \\
\text { specification }\end{array}$ & $\begin{array}{l}(2) \\
\text { Democracy } \\
\text { substituted for } \\
\text { political freedom }\end{array}$ & $\begin{array}{l}(3) \\
\text { Religious } \\
\text { pluralism } \\
\text { added }\end{array}$ & $\begin{array}{l}(4) \\
\text { Physical } \\
\text { investment } \\
\text { added }\end{array}$ & $\begin{array}{l}(5) \\
\text { Income } \\
\text { inequality } \\
\text { added }\end{array}$ & $\begin{array}{l}\text { (6) } \\
\text { Inflation } \\
\text { rate } \\
\text { added }\end{array}$ & $\begin{array}{l}(7) \\
\text { Systemic } \\
\text { banking crises } \\
\text { added }\end{array}$ & $\begin{array}{l}(8) \\
\text { Natural } \\
\text { disasters } \\
\text { added }\end{array}$ & $\begin{array}{l}\text { (9) } \\
\text { Wars } \\
\text { added }\end{array}$ \\
\hline GDP growth rate & $\begin{array}{c}1.25 \\
(17.02)\end{array}$ & $\begin{array}{c}3.06 \\
(17.32)\end{array}$ & $\begin{array}{c}0.81 \\
(17.54)\end{array}$ & $\begin{array}{l}-2.02 \\
(18.04)\end{array}$ & $\begin{array}{c}-21.30 \\
(17.45)\end{array}$ & $\begin{array}{c}2.04 \\
(17.01)\end{array}$ & $\begin{array}{c}1.70 \\
(17.49)\end{array}$ & $\begin{array}{c}1.11 \\
(17.16)\end{array}$ & $\begin{array}{c}1.05 \\
(16.92)\end{array}$ \\
\hline Private credit & $\begin{array}{c}-0.34 \\
(3.56)\end{array}$ & $\begin{array}{c}0.90 \\
(3.83)\end{array}$ & $\begin{array}{c}-0.03 \\
(3.61)\end{array}$ & $\begin{array}{c}-0.58 \\
(3.63)\end{array}$ & $\begin{array}{r}-0.90 \\
(3.79)\end{array}$ & $\begin{array}{c}-0.33 \\
(3.57)\end{array}$ & $\begin{array}{c}-0.37 \\
(3.54)\end{array}$ & $\begin{array}{c}-0.40 \\
(3.54)\end{array}$ & $\begin{array}{r}-0.37 \\
(3.55)\end{array}$ \\
\hline Physical capital stock & $\begin{array}{c}-1.07^{* *} \\
(0.44)\end{array}$ & $\begin{array}{c}-1.16^{* *} \\
(0.45)\end{array}$ & $\begin{array}{c}-1.13^{* *} \\
(0.45)\end{array}$ & $\begin{array}{c}-1.08^{* *} \\
(0.43)\end{array}$ & $\begin{array}{c}-0.93^{* *} \\
(0.44)\end{array}$ & $\begin{array}{c}-1.06^{* *} \\
(0.44)\end{array}$ & $\begin{array}{c}-1.07^{* *} \\
(0.44)\end{array}$ & $\begin{array}{c}-1.07^{* *} \\
(0.44)\end{array}$ & $\begin{array}{c}-1.07^{* *} \\
(0.44)\end{array}$ \\
\hline Openness & $\begin{array}{r}-2.49 \\
(4.55)\end{array}$ & $\begin{array}{r}-2.90 \\
(4.74)\end{array}$ & $\begin{array}{r}-2.46 \\
(4.52)\end{array}$ & $\begin{array}{c}-3.43 \\
(4.67)\end{array}$ & $\begin{array}{c}0.80 \\
(5.05)\end{array}$ & $\begin{array}{c}-2.50 \\
(4.55)\end{array}$ & $\begin{array}{c}-2.51 \\
(4.56)\end{array}$ & $\begin{array}{c}-2.41 \\
(4.57)\end{array}$ & $\begin{array}{r}-2.36 \\
(4.55)\end{array}$ \\
\hline Democracy & & $\begin{array}{c}0.18 \\
(2.90)\end{array}$ & & & & & & & \\
\hline Religious pluralism & & & $\begin{array}{r}-13.21 \\
(16.75)\end{array}$ & & & & & & \\
\hline Physical investment & & & & $\begin{array}{c}11.54 \\
(11.83)\end{array}$ & & & & & \\
\hline Income inequality & & & & & $\begin{array}{l}11.33 \\
(9.77)\end{array}$ & & & & \\
\hline Inflation rate & & & & & & $\begin{array}{c}0.04 \\
(0.05)\end{array}$ & & & \\
\hline Systemic banking crises & & & & & & & $\begin{array}{c}0.25 \\
(2.15)\end{array}$ & & \\
\hline Natural disasters & & & & & & & & $\begin{array}{c}9.11 \\
(18.69)\end{array}$ & \\
\hline Wars & & & & & & & & & $\begin{array}{r}-6.35^{*} \\
(3.45)\end{array}$ \\
\hline Number of observations & 540 & 520 & 540 & 539 & 486 & 539 & 540 & 540 & 540 \\
\hline Number of countries & 109 & 104 & 109 & 108 & 106 & 109 & 109 & 109 & 109 \\
\hline
\end{tabular}


Table 1. (Continued)

\begin{tabular}{|c|c|c|c|c|c|c|c|c|c|}
\hline & $\begin{array}{l}\text { Baseline } \\
\text { specification }\end{array}$ & $\begin{array}{l}\text { (2) } \\
\text { Democracy } \\
\text { substituted for } \\
\text { political freedom }\end{array}$ & $\begin{array}{l}(3) \\
\text { Religious } \\
\text { pluralism } \\
\text { added }\end{array}$ & $\begin{array}{l}(4) \\
\text { Physical } \\
\text { investment } \\
\text { added }\end{array}$ & $\begin{array}{l}\text { (5) } \\
\text { Income } \\
\text { inequality } \\
\text { added }\end{array}$ & $\begin{array}{l}(6) \\
\text { Inflation } \\
\text { rate } \\
\text { added }\end{array}$ & $\begin{array}{l}(7) \\
\text { Systemic } \\
\text { banking crises } \\
\text { added }\end{array}$ & $\begin{array}{l}(8) \\
\text { Natural } \\
\text { disasters } \\
\text { added }\end{array}$ & $\begin{array}{l}\text { Wars } \\
\text { added }\end{array}$ \\
\hline$R^{2}$ within & 0.65 & 0.65 & 0.65 & 0.65 & 0.67 & 0.65 & 0.65 & 0.65 & 0.65 \\
\hline F statistic & $25.17^{* * *}$ & $25.28^{* * *}$ & $22.91^{* * *}$ & $25.62^{* * *}$ & $23.55^{* * *}$ & $23.21^{* * *}$ & $24.86^{* * *}$ & $24.59^{* * *}$ & $24.02^{* * *}$ \\
\hline Standard error of regression & 6.51 & 6.60 & 6.51 & 6.51 & 6.36 & 6.52 & 6.52 & 6.51 & 6.51 \\
\hline Reverse causality test ${ }^{\mathrm{a}}$ & 0.24 & 0.28 & 0.23 & 0.25 & 0.12 & 0.24 & 0.24 & 0.23 & 0.23 \\
\hline \multicolumn{10}{|c|}{ Panel B. Dependent variable: female secondary enrollment rate } \\
\hline Economic freedom & $\begin{array}{l}26.72^{* *} \\
(11.96)\end{array}$ & $\begin{array}{l}25.36^{* *} \\
(12.21)\end{array}$ & $\begin{array}{l}27.30^{* *} \\
(12.11)\end{array}$ & $\begin{array}{l}24.88^{* *} \\
(11.49)\end{array}$ & $\begin{array}{l}31.64^{* *} \\
(12.05)\end{array}$ & $\begin{array}{l}27.22^{* *} \\
(12.08)\end{array}$ & $\begin{array}{l}26.75^{* *} \\
(11.98)\end{array}$ & $\begin{array}{l}26.99^{* *} \\
(11.92)\end{array}$ & $\begin{array}{l}26.18^{* *} \\
(12.04)\end{array}$ \\
\hline Control variables ${ }^{\mathrm{b}}$ & Yes & Yes & Yes & Yes & Yes & Yes & Yes & Yes & Yes \\
\hline Number of observations & 533 & 513 & 533 & 532 & 480 & 532 & 533 & 533 & 533 \\
\hline Number of countries & 108 & 103 & 108 & 107 & 105 & 108 & 108 & 108 & 108 \\
\hline$R^{2}$ within & 0.65 & 0.65 & 0.65 & 0.65 & 0.66 & 0.65 & 0.65 & 0.65 & 0.65 \\
\hline$F$ statistic & $23.13^{* * *}$ & $23.15^{* * *}$ & $21.75^{* * *}$ & $22.60^{* * *}$ & $21.10^{* * *}$ & $21.28^{* * *}$ & $22.47^{* * *}$ & $22.89^{* * *}$ & $22.09^{* * *}$ \\
\hline Reverse causality test ${ }^{\mathrm{a}}$ & 0.22 & 0.27 & 0.22 & 0.23 & 0.16 & 0.22 & 0.22 & 0.22 & 0.22 \\
\hline
\end{tabular}

Notes: Pooled least squares regressions with country-specific fixed effects. The data are non-overlapping 5-year averages spanning 1972 to 2011 . All explanatory variables are lagged by one 5 -year period. All regressions also contain period dummies and a constant term. Robust standard errors, adjusted for clustering at the country level, are reported in parentheses. ${ }^{* * *}(* * *)$ denotes statistically significant at the $1 \%(5 \% / 10 \%)$ level.

${ }^{a} p$ value of coefficient on the respective enrollment variable from a regression in which the dependent variable and the variable of interest are swapped, i.e., 'economic freedom' is used as dependent variable and the respective enrollment variable, lagged by one 5-year period, as an explanatory variable. In each of these tests, the control variables, lagged by one 5-year period, and the estimation method are the same as in the corresponding regression presented in the same column in panel A.

'Each regression of 'female secondary enrollment rate' uses the same control variables as the regression of 'secondary enrollment rate' presented in the same column in panel A. For brevity, the estimates for the control variables from the former regressions are omitted. 
equation with a lag of one 5 -year period. Fifth, our reverse causality test does not provide any evidence of causality running in the opposite direction.

\section{Results}

Before we discuss the results from our multivariate regressions, let us briefly take a look at the bivariate associations between 'economic freedom', on the one hand, and the two enrollment variables, on the other (Figures 1 and 2). Both figures use country averages and show a positive relationship. By and large, over the sample period countries that enjoyed more economic freedom had a higher secondary enrollment rate, both among boys and girls combined as well as among girls only.

Table 1 reports the results from our multivariate regressions. While column 1 presents the results from our baseline specification, columns 2 to 9 present the results from our robustness checks. While panel A reports the results from the regressions to explain the secondary enrollment rate, panel B reports the results from the regressions to explain the female secondary enrollment rate. To save space, panel B presents only the estimates for the 'economic freedom' variable and the test statistic; the estimates for the control variables are omitted. Each regression to explain the female secondary enrollment rate uses the same control variables as the corresponding regression to explain the secondary enrollment rate presented in the same column of panel $\mathrm{A}$.

In each regression, the coefficient on 'economic freedom' is positive and statistically significant, suggesting that, over the sample period, economic freedom probably had a favorable effect on both the secondary and the female secondary enrollment rate. In most robustness checks, the size of the coefficient is similar to the estimate from the respective baseline regression. ${ }^{7}$

According to our regression results, the effect of economic freedom on secondary schooling is likely to have been substantial. Turkey is a case in point. On the 0 -to- 1 scale, its EFW score increased from 0.378 on average over the years $1972-76$ to 0.654 on average over the years 2007-11. Over the same period, Turkey's secondary school enrollment rose substantially, both among boys and girls combined as well as among girls only. Specifically, while the secondary enrollment rate increased from $29.8 \%$ on average over $1972-76$ to $86.3 \%$ on average over 2009-11, the female secondary enrollment rate rose from $17.8 \%$ to $81.4 \%$. Our estimates suggest that Turkey's increase in economic freedom might have caused its secondary enrollment rate to rise by 9.2 percentage points and its female secondary enrollment rate by 7.4 percentage points, ceteris paribus. These

\footnotetext{
${ }^{7}$ In an additional robustness check, we excluded from the sample three randomly drawn countries at a time and re-run both baseline regressions at each step. We repeated this exercise until each country had been excluded once. This test did not materially affect the estimate for 'economic freedom' either (results not reported here).
} 
figures have been calculated using the estimates from the baseline regressions presented in column 1 of Table 1 . Of course, they should be taken with a grain of salt. Still, they illustrate that the magnitude of the effect is likely to have been substantial.

Our regression results corroborate the hypothesis that economic freedom is likely to favorably affect human capital investment. As explained in section 1, economic freedom probably stimulates investment in human capital because it both increases the payoffs from these investments and enables people to keep a larger share of them. Additionally, by facilitating the operation of credit markets, economic freedom is likely to make it easier for people to undertake such investments. As also explained in section 1, in its positive effect on human capital investment, the various dimensions of economic freedom - secure property rights, modest taxation, monetary stability, open markets and light regulation - are likely to complement each other.

Our results are in line with the three previous relevant papers (section 1). In particular, they accord with Dawson (1998), who finds that change in economic freedom has a positive effect on the secondary enrollment rate. Our paper also accords with Aixalá and Fabro (2009), who report that economic freedom Granger-causes primary school enrollment. And finally, our results are in line with King et al.'s (2012), who find that returns to human capital investment are higher in economically free countries. Although our results accord with these studies, our paper adds to this literature in several respects - most importantly by using a much larger number of controls and by estimating the effect of economic freedom on human capital formation not only among males and females jointly but also separately for females.

Finally, a brief comment on the estimates for the control variables (Table 1). Interestingly, few of them are statistically significant. One of the most robust results among the controls is that, during our sample period, a larger share of Muslims in the population was associated with a lower secondary enrollment rate. This is in line with the previous literature (section 2). Another robust finding is that a larger physical capital stock is negatively correlated with the secondary enrollment rate, suggesting that investment in human capital might have been primarily a substitute for rather than a complement to physical capital. This interpretation is tentative though, not least because the coefficient on 'physical investment' is insignificant. Furthermore, we find some, albeit weak evidence that wars might have had a negative impact on secondary schooling, lending support to some of the papers on the link between crises and human capital accumulation. The insignificant results for some of the other variables are also in line with some of the previous literature. For example, various previous papers find political freedom, public spending on education and urbanization to have no significant effect on the secondary enrollment rate (section 2). In addition to these papers, we find several other demographic, religious and economic variables to have no significant effect either. However, what is decisive here is that including 
any of those variables does not alter our main result - namely, that over the period 1972 to 2011 economic freedom was positively correlated with human capital investment.

\section{Conclusion}

There is a large literature studying which factors foster investment in human capital. Our paper contributes to this literature by analyzing a factor that, so far, has been almost completely overlooked - economic freedom. As explained in section 1, the reasoning as to why economic freedom is likely to be an important determinant of human capital investment is similar to the case of investment in physical capital. For both types of capital, more economic freedom increases the return on investing in it, lets investors keep a larger share of the return and makes it easier for them to undertake such investments in the first place. In this paper, we report robust evidence that economic freedom is indeed likely to have increased human capital investment over the period 1972 to 2011. The magnitude of the estimated effect is substantial. Our regressions control for all other major determinants of human capital investment.

As mentioned in section 3, the evidence provided in this paper corresponds to conditional correlations in the data. It does not establish causality. Still, the fact that more economic freedom is consistently correlated with higher human capital investment in the following 5-year period, even after controlling for a myriad of factors, and the fact that there is no such reverse association, is intriguing and suggests that the effect is likely to be causal.

Although our regressions control for many factors and the results are robust, more research is needed. Most importantly, the endogeneity issue needs to be tackled in a better way so that the causal effect of economic freedom on human capital investment can be identified more convincingly. ${ }^{8}$ Furthermore, the transmission channels from economic freedom to human capital investment need to be studied in more in detail, both theoretically and empirically. For example, how does an increase in economic freedom affect parents' decisions about their children's education? Additionally, the effect of economic freedom on other forms of human capital accumulation need to be studied as well. For example, does an increase in economic freedom induce firms to improve the training of their workforce? As education and training are essential for economic development, a better understanding of the role played by economic freedom is an important issue for future research.

\footnotetext{
${ }^{8}$ One way to establish the causal effect of economic freedom on human capital investment might be to perform comparative case studies using the Synthetic Control Method (Abadie et al., 2010, 2015). This method would be applicable in cases where an individual country has implemented a substantial change in economic freedom. Using this method, subsequent human capital investment in the reformer country could be compared with a weighted average set of similar countries - the synthetic control group. Such a control group could constitute a good counterfactual, enabling causal inference.
} 


\section{References}

Abadie, A., A. Diamond, and J. Hainmueller (2010), 'Synthetic Control Methods for Comparative Case Studies: Estimating the Effect of California's Tobacco Control Program', Journal of the American Statistical Association, 105(490): 493-505.

Abadie, A., A. Diamond, and J. Hainmueller (2015), 'Comparative Politics and the Synthetic Control Method', American Journal of Political Science, 59(2): 495-510.

Acemoglu, D. (2005), 'Constitutions, Politics, and Economics: A Review Essay on Persson and Tabellini's The Economic Effects of Constitutions', Journal of Economic Literature, 43(4): 1025-1048.

Acemoglu, D., S. Johnson, and J. A. Robinson (2001), 'The Colonial Origins of Comparative Development: An Empirical Investigation', American Economic Review, 91(5): 13691401.

Aixalá, J. and G. Fabro (2009), 'Economic Freedom, Civil Liberties, Political Rights and Growth: A Causality Analysis', Spanish Economic Review, 11(3): 165-178.

Alesina, A., A. Devleeschauwer, W. Easterly, S. Kurlat, and R. Wacziarg (2003), 'Fractionalization', Journal of Economic Growth, 8(2): 155-194.

Barro, R. J. (1999), 'Determinants of Democracy', Journal of Political Economy, 107(6, 2): S158-S183.

Bazzi, S. and M. A. Clemens (2013), 'Blunt Instruments: Avoiding Common Pitfalls in Identifying the Causes of Economic Growth', American Economic Journal: Macroeconomics, 5(2): 152-186.

Becker, G. S. and H. G. Lewis (1973), 'On the Interaction between the Quantity and Quality of Children', Journal of Political Economy, 81(2, 2): S279-S288.

Becker, S. O. and L. Woessmann (2009), 'Was Weber Wrong? A Human Capital Theory of Protestant Economic History', Quarterly Journal of Economics, 124(2): 531-596.

Besley, T. (1995), 'Property Rights and Investment Incentives: Theory and Evidence from Ghana', Journal of Political Economy, 103(5): 903-937.

Bessey, D. (2013), 'Religion and Educational Attainment in East Asia: First Evidence from the East Asian Social Survey', Global Economic Review, 42(3): 238-250.

Boikos, S., A. Bucci, and T. Stengos (2013), 'Non-Monotonicity of Fertility in Human Capital Accumulation and Economic Growth', Journal of Macroeconomics, 38(A): 44-59.

Burton-Jones, A. and J.-C. Spender (eds.) (2011), The Oxford Handbook of Human Capital, Oxford: Oxford University Press.

Castelló-Climent, A. and A. Hidalgo-Cabrillana (2012), 'The Role of Educational Quality and Quantity in the Process of Economic Development', Economics of Education Review, 31(4): 391-409.

Centre for Research on the Epidemiology of Disasters - CRED (2014), 'International Disasters Database (EM-DAT)', http://www.emdat.be (accessed 20 June 2014).

Cervellati, M. and U. Sunde (2005), 'Human Capital Formation, Life Expectancy, and the Process of Development', American Economic Review, 95(5): 1653-1672.

Chiu, W. H. (1998), 'Income Inequality, Human Capital Accumulation and Economic Performance', Economic Journal, 108(446): 44-59.

Cooray, A. and N. Potrafke (2011), 'Gender Inequality in Education: Political Institutions or Culture and Religion?', European Journal of Political Economy, 27(2): 268-280.

Crespo Cuaresma, J. (2010), 'Natural Disasters and Human Capital Accumulation', World Bank Economic Review, 24(2): 280-302.

Davis, L. S. and F. Abdurazokzoda (2016), 'Language, Culture and Institutions: Evidence from a New Linguistic Dataset', Journal of Comparative Economics, 44(3): 541-561. 
Dawson, J. W. (1998), 'Institutions, Investment, and Growth: New Cross-Country and Panel Data Evidence', Economic Inquiry, 36(4): 603-619.

De Gregorio, J. (1996), 'Borrowing Constraints, Human Capital Accumulation, and Growth', Journal of Monetary Economics, 37(1): 49-71.

Demirgüç-Kunt, A. and V. Maksimovic (1998), 'Law, Finance, and Firm Growth', Journal of Finance, 53(6): 2107-2137.

Eterovic, D. S. and C. M. Sweet (2014), 'Democracy and Education in Twentieth-Century Latin America', Economics and Politics, 26(2): 237-262.

Faria, H. J. and H. M. Montesinos (2009), 'Does Economic Freedom Cause Prosperity? An IV Approach', Public Choice, 141(1-2): 103-127.

Feenstra, R. C., R. Inklaar, and M. P. Timmer (2013), 'Penn World Table 8.0', http://www.rug.nl/research/ggdc/data/penn-world-table (accessed 23 July 2013).

Feldmann, H. (2016a), 'Which Religions Still Affect Schooling? A Study of 143 Countries', Comparative Sociology, 15(4): 439-484.

Feldmann, H. (2016b), 'The Long Shadows of Spanish and French Colonial Education', Kyklos, 69(1): 32-64.

Flug, K., A. Spilimbergo, and E. Wachtenheim (1998), 'Investment in Education: Do Economic Volatility and Credit Constraints Matter?', Journal of Development Economics, 55(2): $465-481$.

Forston, J. G. (2011), 'Mortality Risk and Human Capital Investment: The Impact of HIV/AIDS in Sub-Saharan Africa', Review of Economics and Statistics, 93(1): $1-15$.

Freedom House (2014), Freedom in the World 2014, https://freedomhouse.org (accessed 20 April 2014).

Glaeser, E. L., R. La Porta, F. Lopez-de-Silanes, and A. Shleifer (2004), 'Do Institutions Cause Growth?', Journal of Economic Growth, 9(3): 271-303.

Griliches, Z. (1969), 'Capital-Skill Complementarity', Review of Economics and Statistics, 51(4): 465-468.

Grossmann, V. (2008), 'Risky Human Capital Investment, Income Distribution, and Macroeconomic Dynamics', Journal of Macroeconomics, 30(1): 19-42.

Gruber, J. H. (2005), 'Religious Market Structure, Religious Participation, and Outcomes: Is Religion Good for You?', Advances in Economic Analysis and Policy, 5(1): 1-30.

Gwartney, J. D., R. A. Lawson, and J. C. Hall (2013), Economic Freedom of the World: 2013 Annual Report, Vancouver, BC: Fraser Institute.

Hall, J. C. and R. A. Lawson (2014), 'Economic Freedom of the World: An Accounting of the Literature', Contemporary Economic Policy, 32(1): 1-19.

Hall, R. E. and C. I. Jones (1999), 'Why Do Some Countries Produce So Much More Output per Worker than Others?', Quarterly Journal of Economics, 114(1): 83-116.

Hansen, L. P. (1982), 'Large Sample Properties of Generalized Method of Moments Estimators', Econometrica, 50(4): 1029-1054.

Hanushek, E. A. (1992), 'The Trade-off between Child Quantity and Quality', Journal of Political Economy, 100(1): 84-117.

Hausman, J. A. (1978), 'Specification Tests in Econometrics', Econometrica, 46(6): 12511271.

Hausman, J. A. and W. E. Taylor (1981), 'Panel Data and Unobservable Individual Effects', Econometrica, 49(6): 1377-1398.

Heylen, F. and L. Pozzi (2007), 'Crises and Human Capital Accumulation', Canadian Journal of Economics, 40(4): 1261-1285. 
IMF (2014), 'World Economic Outlook Database, April 2014 Edition', http://www.imf.org (accessed 9 May 2014).

Kalemli-Ozcan, S., H. E. Ryder, and D. N. Weil (2000), 'Mortality Decline, Human Capital Investment, and Economic Growth', Journal of Development Economics, 62(1): 1-23.

King, E. M., C. E. Montenegro, and P. F. Orazem (2012), 'Economic Freedom, Human Rights, and the Returns to Human Capital: An Evaluation of the Schultz Hypothesis', Economic Development and Cultural Change, 61(1): 39-72.

Kleibergen, F. and R. Paap (2006), 'Generalized Reduced Rank Tests Using the Singular Value Decomposition', Journal of Econometrics, 133(1): 97-126.

Laeven, L. and F. Valencia (2013), 'Systemic Banking Crises Database', IMF Economic Review, 61(2): 225-270.

Lake, D. A. and M. A. Baum (2001), 'The Invisible Hand of Democracy: Political Control and the Provision of Public Services', Comparative Political Studies, 34(6): 587-621.

La Porta, R., F. Lopez-de-Silanes, A. Shleifer, and R. Vishny (1999), 'The Quality of Government', Journal of Law, Economics, and Organization, 15(1): 222-279.

Lipset, S. M. (1960), Political Man: The Social Bases of Politics, Garden City, NY: Doubleday. Maoz, Z. and E. A. Henderson (2013), 'The World Religion Dataset, Version 1.1', http://www.correlatesofwar.org (accessed 11 February 2014).

Marshall, M. G., T. R. Gurr, and K. Jaggers (2014), 'Polity IV Project: Political Regime Characteristics and Transitions, 1800-2013, Version 2013', http://www.systemicpeace.org (accessed 4 June 2014).

Méndez, F. and F. Sepúlveda (2012), 'The Cyclicality of Skill Acquisition: Evidence from Panel Data', American Economic Journal: Macroeconomics, 4(3): 128-152.

Miller, T. and A. B. Kim (2016), 2016 Index of Economic Freedom, Washington, DC: Heritage Foundation, New York: Wall Street Journal.

Mincer, J. (1996), 'Economic Development, Growth of Human Capital, and the Dynamics of the Wage Structure', Journal of Economic Growth, 1(1): 29-48.

Neal, D. (1997), 'The Effects of Catholic Secondary Schooling on Educational Achievement', Journal of Labor Economics, 15(1, 1): 98-123.

Norton, S. W. and A. Tomal (2009), 'Religion and Female Educational Attainment', Journal of Money, Credit and Banking, 41(5): 961-986.

Papagapitos, A. and R. Riley (2009), 'Social Trust and Human Capital Formation', Economics Letters, 102(3): 158-160.

Ranjan, P. (2001), 'Dynamic Evolution of Income Distribution and Credit-Constrained Human Capital Investment in Open Economies', Journal of International Economics, 55(2): 329-358.

Roodman, D. (2009a), 'A Note on the Theme of Too Many Instruments', Oxford Bulletin of Economics and Statistics, 71(1): 135-158.

Roodman, D. (2009b), 'How to Do xtabond2: An Introduction to Difference and System GMM in Stata', Stata Journal, 9(1): 86-136.

Rudra, N. and S. Haggard (2005), 'Globalization, Democracy, and Effective Welfare Spending in the Developing World', Comparative Political Studies, 38(9): 1015-1049.

Schultz, T. W. (1975), 'The Value of the Ability to Deal with Disequilibria', Journal of Economic Literature, 13(3): 827-846.

Shea, J. (1997), 'Instrument Relevance in Multivariate Linear Models: A Simple Measure', Review of Economics and Statistics, 49(2): 348-352.

Sherkat, D. E. (2011), 'Religion and Scientific Literacy in the United States', Social Science Quarterly, 92(5): 1134-1150. 
Skidmore, M. and H. Toya (2002), 'Do Natural Disasters Promote Long-Run Growth?', Economic Inquiry, 40(4): 664-687.

Soares, R. R. (2005), 'Mortality Reductions, Educational Attainment, and Fertility Choice', American Economic Review, 95(3): 580-601.

Solt, F. (2013), 'Standardized World Income Inequality Database, Version 4', http://myweb.uiowa.edu/fsolt/swiid/swiid.html (accessed 24 October 2013).

Staiger, D. and J. H. Stock (1997), 'Instrumental Variables Regression with Weak Instruments', Econometrica, 65(3): 557-586.

Stoler, A. and D. Meltzer (2013), 'Mortality and Morbidity Risks and Economic Behavior', Health Economics, 22(2): 132-143.

UNESCO Institute for Statistics (2015), 'Education Statistics', http://www.uis.unesco.org (accessed 2 September 2015).

World Bank (2013), 'Global Financial Development Database', http://data.worldbank.org (accessed 6 January 2014).

World Bank (2014), 'World Development Indicators', http://data.worldbank.org (accessed 6 June 2014). 


\section{Appendix A}

Table A1. List of variables

\begin{tabular}{|c|c|c|c|c|c|c|}
\hline & Definition & Mean & Std. dev. & Min. & Max. & Source \\
\hline Death rate & Number of deaths per 1,000 people. & 9.78 & 4.09 & 2.54 & 35.48 & World Bank (2014) \\
\hline Democracy & $\begin{array}{l}\text { 'Polity2' index, scaled to range from } 0 \text { (strongly autocratic) to } \\
1 \text { (strongly democratic). The index measures the degree of } \\
\text { autocracy/democracy based on the competitiveness and } \\
\text { regulation of political participation, the openness and } \\
\text { competitiveness of executive recruitment and the constraints } \\
\text { on the chief executive of the political regime. }\end{array}$ & 0.70 & 0.34 & 0.00 & 1.00 & Marshall et al. (2014) \\
\hline $\begin{array}{l}\text { Eastern religions } \\
\text { population }\end{array}$ & $\begin{array}{l}\text { Decimal fraction of the population adhering to an Eastern } \\
\text { religion (Buddhism, Confucianism, Hinduism, Jainism, } \\
\text { Shinto, Sikhism, Taoism). }\end{array}$ & 0.06 & 0.18 & 0.00 & 0.91 & $\begin{array}{l}\text { Maoz and Henderson } \\
\text { (2013); author's } \\
\text { calculations }\end{array}$ \\
\hline Economic freedom & $\begin{array}{l}\text { 'Economic Freedom of the World (EFW)' chain-linked } \\
\text { summary index, scaled to range from } 0 \text { (least free) to } 1 \\
\text { (most free). The index measures the degree of economic } \\
\text { freedom in the following five areas: size of government, } \\
\text { legal system and property rights, sound money, freedom to } \\
\text { trade internationally, regulation. The summary ratings of } \\
\text { the index are the arithmetic means of the area ratings. }\end{array}$ & 0.60 & 0.12 & 0.29 & 0.86 & $\begin{array}{l}\text { Gwartney et al. }(2013) ; \\
\text { author's calculations }\end{array}$ \\
\hline $\begin{array}{l}\text { Female secondary } \\
\text { enrollment rate }\end{array}$ & $\begin{array}{l}\text { Girls enrolled in secondary education, regardless of age, as a } \\
\text { percentage of girls in the age group that officially } \\
\text { corresponds to this level of education. }\end{array}$ & 70.31 & 33.90 & 2.30 & 167.37 & $\begin{array}{l}\text { UNESCO Institute for } \\
\text { Statistics (2015) }\end{array}$ \\
\hline GDP growth rate & Annual growth rate of real GDP; decimal fraction. & 0.04 & 0.03 & -0.14 & 0.20 & $\begin{array}{l}\text { IMF (2014); World Bank } \\
\text { (2014) }\end{array}$ \\
\hline GDP per capita & $\begin{array}{l}\text { Expenditure side real GDP per capita at chained purchasing } \\
\text { power parity rates, in tens of thousands of } 2005 \text { US dollars. }\end{array}$ & 1.06 & 1.02 & 0.02 & 5.60 & $\begin{array}{l}\text { Feenstra et al. }(2013) \\
\text { author's calculations }\end{array}$ \\
\hline
\end{tabular}


Table A1. (Continued)

\begin{tabular}{|c|c|c|c|c|c|c|}
\hline & Definition & Mean & Std. dev. & Min. & Max. & Source \\
\hline Income inequality & $\begin{array}{l}\text { Standardized Gini coefficients of inequality in household } \\
\text { market (pre-tax, pre-transfer) income, scaled to take values } \\
\text { between } 0 \text { (perfect equality) and } 1 \text { (perfect inequality). }\end{array}$ & 0.44 & 0.09 & 0.21 & 0.75 & Solt (2013) \\
\hline Inflation rate & Annual change in the consumer price index; decimal fraction. & 0.36 & 2.99 & -0.04 & 61.85 & $\begin{array}{l}\text { IMF (2014); World Bank } \\
\text { (2014) }\end{array}$ \\
\hline Life expectancy & Life expectancy at birth in years. & 67.07 & 10.08 & 29.69 & 81.92 & World Bank (2014) \\
\hline Muslim population & Decimal fraction of the population adhering to Islam. & 0.18 & 0.32 & 0.00 & 0.99 & $\begin{array}{l}\text { Maoz and Henderson } \\
\text { (2013) }\end{array}$ \\
\hline Natural disasters & $\begin{array}{l}\text { Total number of persons affected by natural disasters as a } \\
\text { decimal fraction of the population. Natural disasters include } \\
\text { climate-related disasters (e.g., storms, floods and droughts), } \\
\text { geological disasters (e.g., earthquakes, volcanic eruptions) } \\
\text { and biological disasters (e.g., epidemics, insect infestations). } \\
\text { For a disaster to be counted, it needs to meet at least one of } \\
\text { the following criteria: } 10 \text { or more people reported killed, } \\
100 \text { or more people reported otherwise affected, a state of } \\
\text { emergency was declared or a call for international assistance } \\
\text { was issued. Total number of persons affected includes those } \\
\text { killed, injured, homeless or requiring immediate assistance. }\end{array}$ & 0.01 & 0.03 & 0.00 & 0.23 & $\begin{array}{l}\text { Centre for Research on the } \\
\text { Epidemiology of } \\
\text { Disasters - CRED (2014); } \\
\text { World Bank (2014); } \\
\text { author's calculations }\end{array}$ \\
\hline Openness & $\begin{array}{l}\text { Sum of exports and imports of goods and services as a decimal } \\
\text { fraction of GDP. }\end{array}$ & 0.71 & 0.37 & 0.13 & 2.53 & World Bank (2014) \\
\hline Physical capital stock & $\begin{array}{l}\text { Real physical capital stock at constant } 2005 \text { national prices, in } \\
\text { trillion } 2005 \text { US dollars. }\end{array}$ & 1.01 & 3.24 & 0.00 & 36.64 & Feenstra et al. (2013) \\
\hline Physical investment & $\begin{array}{l}\text { Gross capital formation as a decimal fraction of GDP. It } \\
\text { consists of outlays on additions to the fixed assets of the } \\
\text { economy plus net changes in the level of inventories. }\end{array}$ & 0.22 & 0.06 & 0.02 & 0.41 & World Bank (2014) \\
\hline
\end{tabular}


Table A1. (Continued)

\begin{tabular}{|c|c|c|c|c|c|c|}
\hline & Definition & Mean & Std. dev. & Min. & Max. & Source \\
\hline Political freedom & $\begin{array}{l}\text { Average of political rights and civil liberties ratings. Political } \\
\text { rights include the right to form political parties, to compete } \\
\text { for public office and to elect representatives who have a } \\
\text { decisive vote on public policies. Civil liberties include } \\
\text { religious, ethnic, economic, linguistic, gender and family } \\
\text { rights, personal freedoms and freedom of the press, belief } \\
\text { and association. The index, which is based on surveys } \\
\text { among analysts and academics, is scaled to range from } 0 \text { to } \\
\text { 1, with higher values representing more political rights and } \\
\text { civil liberties (or more respect for or more protection of } \\
\text { political rights and civil liberties). }\end{array}$ & 0.66 & 0.30 & 0.00 & 1.00 & $\begin{array}{c}\text { Freedom House (2014); } \\
\text { author's calculations }\end{array}$ \\
\hline Population growth rate & Annual growth rate of the population; decimal fraction. & 0.02 & 0.01 & -0.03 & 0.08 & World Bank (2014) \\
\hline Private credit & $\begin{array}{l}\text { The financial resources provided to the private sector by } \\
\text { deposit money banks and other financial institutions as a } \\
\text { decimal fraction of GDP. Domestic money banks comprise } \\
\text { commercial banks and other financial institutions that } \\
\text { accept transferable deposits, such as demand deposits. }\end{array}$ & 0.44 & 0.39 & 0.00 & 2.17 & World Bank (2013) \\
\hline Protestant population & Decimal fraction of the population adhering to Protestantism. & 0.17 & 0.24 & 0.00 & 0.94 & $\begin{array}{l}\text { Maoz and Henderson } \\
\text { (2013) }\end{array}$ \\
\hline $\begin{array}{l}\text { Public spending on } \\
\text { education }\end{array}$ & $\begin{array}{l}\text { Public spending on education as a decimal fraction of GDP. It } \\
\text { consists of current and capital public expenditure on } \\
\text { education and includes government spending on educational } \\
\text { institutions (both public and private), education } \\
\text { administration as well as subsidies for private entities } \\
\text { (students/households and other private entities). }\end{array}$ & 0.04 & 0.02 & 0.01 & 0.36 & World Bank (2014) \\
\hline
\end{tabular}


Table A1. (Continued)

\begin{tabular}{|c|c|c|c|c|c|c|}
\hline & Definition & Mean & Std. dev. & Min. & Max. & Source \\
\hline Religious pluralism & $\begin{array}{l}\text { One minus the Herfindahl index of religious group shares, } \\
\text { reflecting the probability that two randomly selected } \\
\text { individuals from a population belong to different groups. }\end{array}$ & 0.29 & 0.19 & 0.02 & 0.71 & $\begin{array}{l}\text { Maoz and Henderson } \\
\text { (2013); author's } \\
\text { calculations }\end{array}$ \\
\hline $\begin{array}{l}\text { Roman Catholic } \\
\text { population }\end{array}$ & $\begin{array}{l}\text { Decimal fraction of the population adhering to Roman } \\
\text { Catholic religion. }\end{array}$ & 0.35 & 0.36 & 0.00 & 0.98 & $\begin{array}{l}\text { Maoz and Henderson } \\
\text { (2013) }\end{array}$ \\
\hline $\begin{array}{l}\text { Secondary enrollment } \\
\text { rate }\end{array}$ & $\begin{array}{l}\text { Children enrolled in secondary education, regardless of age, as } \\
\text { a percentage of the age group that officially corresponds to } \\
\text { this level of education. }\end{array}$ & 70.99 & 31.75 & 3.42 & 154.82 & $\begin{array}{l}\text { UNESCO Institute for } \\
\text { Statistics (2015) }\end{array}$ \\
\hline Systemic banking crises & $\begin{array}{l}\text { Dummy variable that takes the value } 1 \text { if, in the respective } \\
\text { year, the country experienced a systemic banking crisis. A } \\
\text { banking crisis is defined as systemic if two conditions are } \\
\text { met: first, significant signs of financial distress in the } \\
\text { banking system (as indicated by significant bank runs, losses } \\
\text { in the banking system or bank liquidations) and second, } \\
\text { significant banking policy intervention measures in response } \\
\text { to significant losses in the banking system. }\end{array}$ & 0.08 & 0.21 & 0.00 & 1.00 & $\begin{array}{l}\text { Laeven and Valencia } \\
\text { (2013) }\end{array}$ \\
\hline Urbanization rate & $\begin{array}{l}\text { People living in urban areas as a decimal fraction of the total } \\
\text { population. }\end{array}$ & 0.55 & 0.23 & 0.04 & 0.98 & World Bank (2014) \\
\hline Wars & $\begin{array}{l}\text { Military and civilian deaths in battle-related conflicts, per } \\
1,000 \text { people. }\end{array}$ & 0.01 & 0.05 & 0.00 & 0.96 & $\begin{array}{l}\text { World Bank (2014); } \\
\text { author's calculations }\end{array}$ \\
\hline
\end{tabular}




\section{Appendix B. List of countries}

Albania, Argentina, Australia, Austria, Bahamas, Bahrain, Bangladesh, Barbados, Belgium, Belize, Benin, Bolivia, Botswana, Bulgaria, Burundi, Cameroon, Canada, Central African Republic, Chad, China, Colombia, Costa Rica, Côte d'Ivoire, Croatia, Cyprus, Czech Republic, Democratic Republic of the Congo, Denmark, Dominican Republic, Ecuador, Egypt, El Salvador, Estonia, Fiji, Finland, France, Gabon, Germany, Ghana, Greece, Guatemala, Guinea Bissau, Honduras, Hungary, Iceland, India, Indonesia, Iran, Ireland, Israel, Italy, Jamaica, Japan, Jordan, Kenya, Kuwait, Latvia, Lithuania, Luxembourg, Madagascar, Malawi, Malaysia, Mali, Malta, Mauritius, Mexico, Morocco, Namibia, Nepal, Netherlands, New Zealand, Niger, Nigeria, Norway, Oman, Pakistan, Panama, Paraguay, Peru, Philippines, Poland, Portugal, Republic of the Congo, Romania, Russia, Rwanda, Senegal, Slovakia, Slovenia, South Africa, South Korea, Spain, Sri Lanka, Sweden, Switzerland, Syria, Tanzania, Thailand, Togo, Trinidad and Tobago, Tunisia, Turkey, Uganda, Ukraine, United Kingdom, United States, Uruguay, Zambia, Zimbabwe. 